\title{
Collaborative Problem-Solving Based on Mobile Multimedia
}

\author{
https://doi.org/10.3991/ijim.v15i13.23765
}

\author{
Endah Hendarwati $(\bowtie)$
}

Universitas Negeri Surabaya, Surabaya, Indonesia

Universitas Muhammadiyah Surabaya, Surabaya, Indonesia

endah.17070996007@mhs.unesa.ac.id

Luthfiyah Nurlaela, Bachtiar Syaiful Bachri

Universitas Negeri Surabaya, Surabaya, Indonesia

\begin{abstract}
The development of mobile technology has an important role to play in achieving 21 st-century skills. Collaborative skills and problem-solving are seen as fundamental skills for achieving 21 st-century skills as a whole. This study aims to develop collaborative problem-solving based on mobile multimedia (CPMM) to achieve student collaborative and problem-solving skills. Multimedia development life cycle (MDLC) is used as a research method to develop CPMM. The CPMM was developed by involving 100 students at the Universitas Muhammadiyah Surabaya, Indonesia. The CPMM development result consisted of three main features. The first feature was the homepage which was used to show student profiles and progress in the course. The second feature was collaborative to become a forum for students to discuss and interact in multi-way mobile ways to solve problems. The third feature was evaluation as tasks from a lecturer to individual students to solve problems. In addition, the study results showed that CPMM was valid and effective for improving students' collaborative and problem-solving skills. This study recommends that CPMM can be used as an essential study and the basis for lecturers and practitioners to develop 21stcentury student skills as a whole (not only collaborative and problem-solving skills) to produce graduates who are ready to face the revolutionary era 4.0.
\end{abstract}

Keywords - Mobile technology, collaborative, problem solving

\section{Introduction}

The development of information and technology in the era of revolution 4.0 provided a considerable challenge for the world of education to achieve 21 st-century skills. However, the use and development of existing technology had not fully achieved 21 st-century skills [1]. Experts had mentioned the 21st-century skills needed by students today include collaborative skills, problem-solving, critical thinking, literacy, creativity, communication, and socio-cultural [2],[3]. 
Based on the evaluation of the 2021 Internationale Program for Student Assessment (PISA), it showed that students' 21st-century skills had decreased cognitive development [4]. Meanwhile, the results of previous studies indicated that 21st-century skills could be achieved by utilizing and developing technology appropriately and adequately [5],[6]. In contrast to other 21 st century skills, collaborative skills and problem solving were essential and fundamental skills to achieve other 21st century skills in critical thinking, literacy, creativity, communication, and socio-cultural [7]. Other research results showed that 21 st-century skills could be achieved by habituating and using technology that focused on collaborative skills and digital problem solving [8]. Collaborative skills in using technology refer to student activities that involve productive interactions, giving arguments, and discussions in solving problems digitally [9]. Meanwhile, problem-solving skills in using technology refer to students' skills in developing and using strategies to find digital solutions [1].

Interactive multimedia mobile has the potential to develop and achieve collaborative skills and problem-solving appropriately. Interactive multimedia mobile has been designed prominently for learning different from the classroom [10],[11]. Their low cost and ease of use of mobile devices make their integration into everyday classroom routines an attractive option. The most promising feature of a mobile learning context is carrying out activities in a more collaborative manner [12]. Previous research results also showed that research in learning technology for the classroom and developments in collaborative learning supported by mobile computers had provided evidence of collaborative learning and problem-solving activities supported by mobile devices that were effective in classrooms [13].

Based on the explanations above, there was a gap between the problem and the need for collaborative and problem-solving skills through adequate interactive multimedia mobile availability. However, interactive multimedia mobile has not specifically exercised collaborative skills and digital student problem solving until now. Therefore, an interactive multimedia mobile is needed that can improve student collaborative skills and problem-solving. In this study, interactive mobile multimedia, which is developed, is called collaborative problem-solving based mobile multimedia (CPMM). The meaning of the term "based" in CPMM is that CPMM is developed by paying attention to collaborative elements in terms of multidirectional interactions between students in groups and lecturers during discussions to solve open problems digitally through mobile learning [14],[15].

\section{Research Methods}

\section{$2.1 \quad$ Research methods}

The research method in this study was adapted from the technology development method, namely, multimedia development life cycle, which consists of five stages, namely concept, design, material collecting, assembly, and testing [16]. The stages of the multimedia development life cycle are shown in Table 1. 
Table 1. The development stages of the CPMM

\begin{tabular}{|l|l|}
\hline \multicolumn{1}{|c|}{ Stage } & \multicolumn{1}{c|}{ Description } \\
\hline Concept & $\begin{array}{l}\text { Formulating the basics of the CPMM project to be developed. Especially re- } \\
\text { garding the objectives and types of CPMM projects to be made. }\end{array}$ \\
\hline Design & $\begin{array}{l}\text { Explaining in detail what would be done and how the CPMM project would } \\
\text { be made. Manuscript creation or navigation and other design processes must } \\
\text { be carried out in full. At this stage, the developer needed to know how the fi- } \\
\text { nal project would be done. }\end{array}$ \\
\hline Obtaining Content Material & $\begin{array}{l}\text { Preparing all the materials needed in the CPMM project. Regarding the mate- } \\
\text { rial to be delivered, multimedia files such as audio, video and images would } \\
\text { be included in the CPMM project presentation. }\end{array}$ \\
\hline Assembly & $\begin{array}{l}\text { Making CPMM features according to design stages and prepare multimedia } \\
\text { file materials. This process required the ability of experts to get good results. }\end{array}$ \\
\hline Testing & $\begin{array}{l}\text { Carrying out further testing of the CPMM project. The trial was carried out } \\
\text { by applying the results of the CPMM project to learning. This was so that } \\
\text { what had been made previously was true before it can be applied in mass } \\
\text { learning. }\end{array}$ \\
\hline
\end{tabular}

\subsection{Participants}

Participants in this study consisted of 100 third-semester students taking learning strategies courses at the Department of Early Childhood Education, Universitas $\mathrm{Mu}-$ hammadiyah Surabaya, Indonesia. The participants consisted of 50 male and female students who were determined proportionally to the random stratification sampling, which is determined by parcels, which was carried out randomly by giving equal opportunities to all students to be the research sample [17].

\subsection{Data collection tools and data analysis}

Data Collection Tools in this study consisted of CPMM validation sheets, Observation of collaborative skills (OCS), and problem-solving skills test (PST). The CPMM evaluation sheet consisted of three assessment components: the relevance of the topic, the relevance of mobile multimedia, and the practicality of mobile multimedia.

Three expert lecturers of mobile technology carried out the CPMM validation sheet. Meanwhile, OCS contains collaborative components consisting of group collaboration, multi-way interactions, group decision making [18]. Results from OCS were recorded automatically in the CPMM discussion feature with a conversion value of $0-100$. Then the PST contained three problem topics about cases of student learning disabilities that students must found the right learning strategy. The PST indicator was adopted from Polya to understand problems, plan solutions, implement solutions, and check again [19]. The PST results were recorded automatically in the CPMM evaluation feature with a conversion value of 0-100. In this study, OCS and PST had gone through a series of trials involving 40 Early School Teacher Education students at the Universitas $\mathrm{Mu}-$ hammadiyah Surabaya, Indonesia (other than those who became research participants). The test results on the OCS and PST, respectively, get a validity value by calculating the product-moment correlation of 0.027 and 0.025. Meanwhile, the OCS and PST 
reliability values used in the Cronbach alpha calculation are 0.014 and 0.012 . Therefore, the OCS and PST have been said to be valid and reliable [20].

The data analysis in this study used the independent sample t-test to measure the effectiveness of the CPMM application on students' collaborative skills and problemsolving. The significance value of the application of CPMM was obtained by comparing the value of $t$ count with $t$ table (1.98) [20].

\section{Results and Discussion}

\subsection{Concept and design}

In the concept stage, a mapping of learning activities in CPMM was made based on collaborative and problem-solving elements (see Fig. 1). The mapping of student learning activities at CPMM began with giving problem statements to students. Students solved the problems in individual tasks, collaborated in groups, and finally presented their discussions in class.

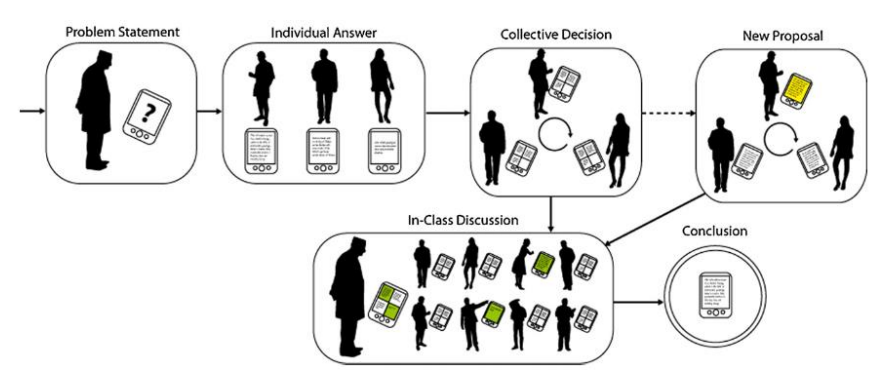

Fig. 1. Mapping mobile activities on CPMM

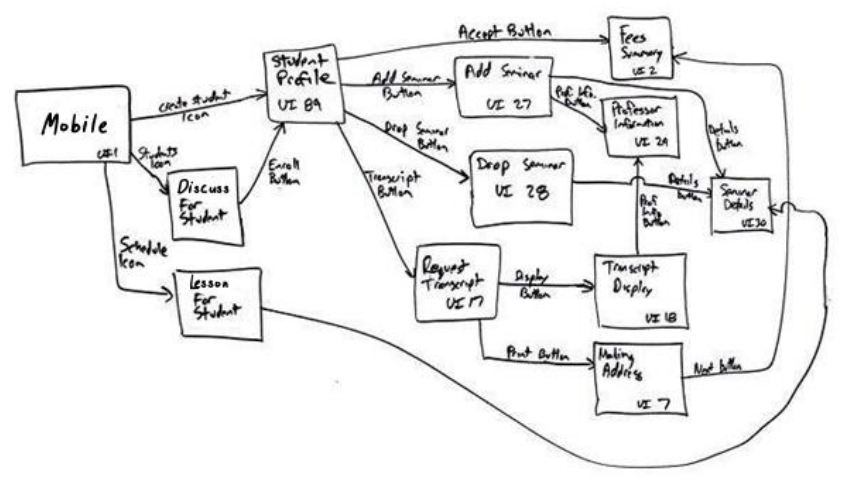

Fig. 2. Navigate the storyboard interface on CPMM

At the design stage, two main steps were carried out. First, setting up an AIR system for android was used to monitor, control, and manage CPMM remotely. In addition, the 
CPMM was developed in the form of an application in the file.apk format with a portrait layout at a size of 1080x1920 pixels. Second, making a storyboard on the CPMM (see Fig. 2). Story-boarding served to map the interface navigation paths on all CPMM features and components so that CPMM had a directed and systematic use. The CPMM is developed on three main features. The first feature was the homepage which was used to show student profiles and progress from the learning strategy course. The second feature was collaborative to become a place for students to discuss, interacting in multidirectional ways, and making decisions on a mobile basis to solve problems. The third feature was evaluation to measure student problem-solving skills individually through problem statements.

\subsection{Obtaining content material and assembly}

At the obtaining stage, the material content was carried out by planning the material in the CPMM by identifying the selection of basic competencies, indicators, and topics in the subject with the applicable curriculum. Then, make a summary of the material, compile content to make learning videos that connect with daily life problems, and create problems that will be given to students as material for collaborative group discussions and individual evaluations.

It begins with coding and processing the materials obtained from the obtaining content material through visual code at the assembly stage. This is also done to make the initial features of the CPMM in the form of a homepage, collaborative and evaluation (see Fig. 3).

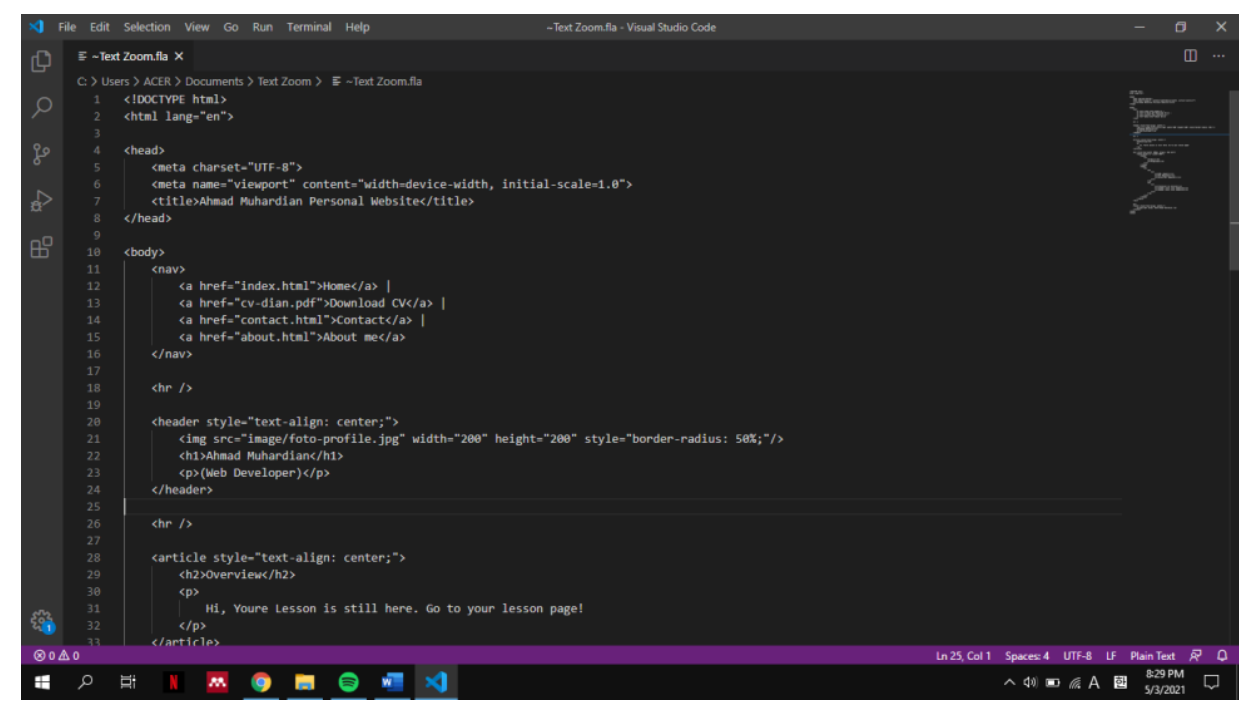

Fig. 3. Coding process on CPMM

The results of the CPMM development on the home page feature consisted of student profiles, courses are taken, course progress, as well as group and individual scores on 
the use of CPMM (see Fig. 4). In the collaborative feature, there were several tasks that students must complete in groups by way of multidirectional discussions and interactions, including with lecturers to make appropriate decisions about problem-solving strategies. Students could also be assigned or shared tasks to group members using the create new task menu (see Fig. 5.a). So that students could have roles, responsibilities, and structured tasks. In addition, in this feature, students and lecturers can find out the student's performance in each group due to collaboration in solving problems (see Fig. 5.b).

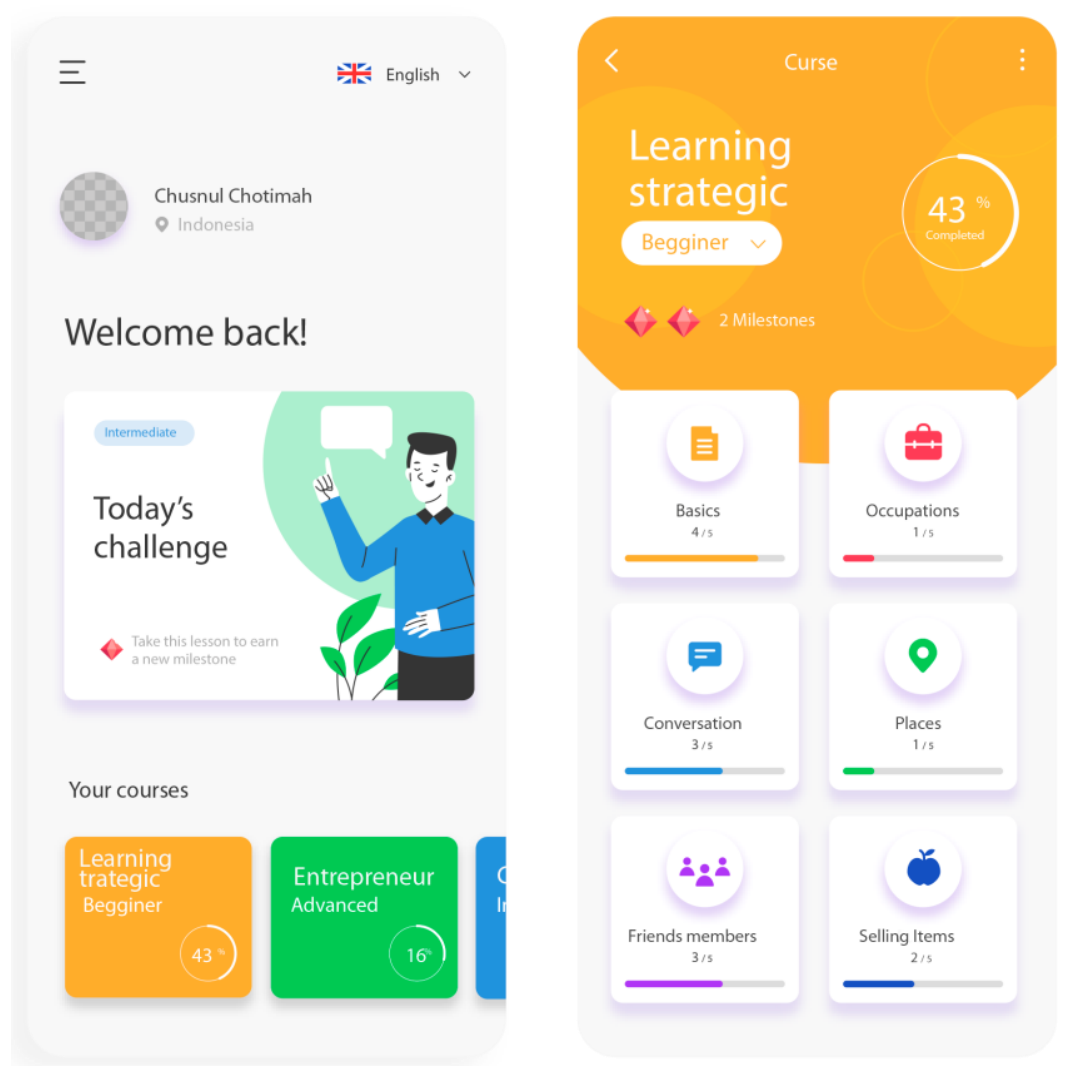

Fig. 4. Homepage feature on CPMM

In the evaluation feature, there was a tasks menu and an answer column to determine the achievement of individual student problem-solving skills (see Fig. 6.a). In this feature, students and lecturers could also find out the results of individual problem-solving skills (see Fig. 6.b). 


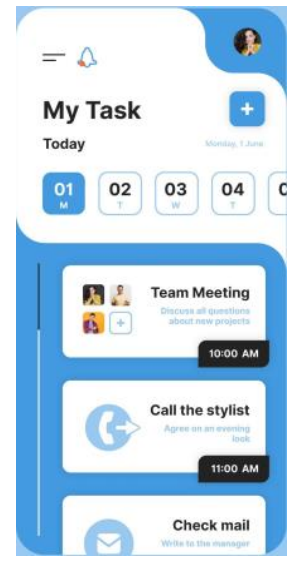

a) Collaborative features on CPMM
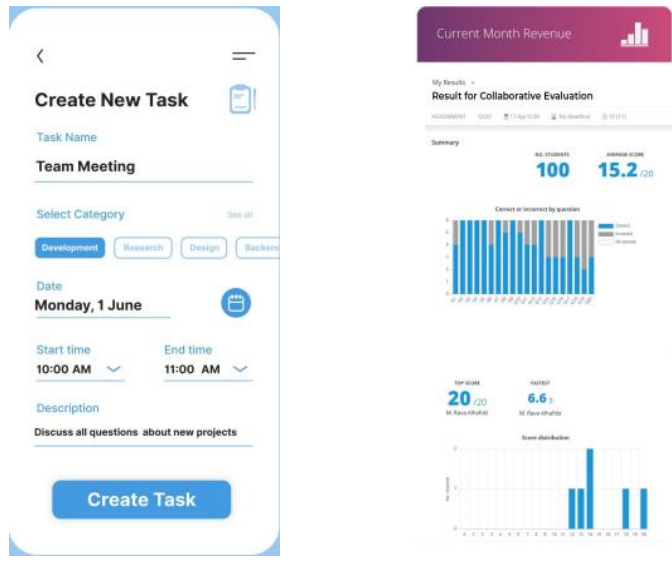

b) The results of scoring student performance on collaborative features on CPMM

Fig. 5.

\subsection{Testing}

At the testing stage, the researcher conducted a theoretical CPMM validity test on the expert. The results of this validity test were categorized into three assessment components: topic relevance, mobile relevance, and mobile practicality. In addition, an empiric test for the use of CPMM was carried out by analyzing the homogeneity test results, normality test, and t-test.

Table 2. Validation results from experts on CPMM

\begin{tabular}{|l|l|l|l|c|}
\hline \multicolumn{1}{|c|}{ Categories } & V1 & V2 & V3 & Average \\
\hline Topic relevance & 3.3 & 3.5 & 3.4 & 3.4 \\
\hline Mobile relevance & 3.7 & 3.7 & 3.7 & 3.7 \\
\hline Mobile practicality & 3.6 & 3.5 & 3.6 & 3.6 \\
\hline
\end{tabular}

In Table 2, it is found that the average rating criteria of the experts for each category of assessment were topic relevance 3.4 (valid), mobile relevance 3.7 (very valid), and mobile practicality (very valid). In other words, CPMM met the standard criteria of valid or feasible use in a mobile learning environment to improve collaborative skills and student problem-solving. 
Table 3. Homogeneity test

\begin{tabular}{|l|l|c|c|c|c|}
\hline \multicolumn{2}{|c|}{} & Levene Statistic & df1 & df2 & Sig. \\
\hline \multirow{5}{*}{ CS } & Based on mean & .435 & 1 & 100 & .695 \\
& Based on median & .422 & 1 & 100 & .725 \\
& Based on median and with adjusted df & .422 & 1 & 95.728 & .725 \\
& Based on trimmed mean & .454 & 1 & 100 & .699 \\
\hline \multirow{5}{*}{ PS } & Based on mean & .404 & 1 & 100 & .499 \\
& Based on median & .385 & 1 & 100 & .519 \\
& Based on median and with adjusted df & .385 & 1 & 98.979 & .519 \\
& Based on trimmed mean & .409 & 1 & 100 & .506 \\
\hline
\end{tabular}

Information:

$\mathrm{CA}=$ Collaborative skills

PSA $=$ Problem solving skills

Table 4. Normality test

\begin{tabular}{|l|c|c|c|c|c|c|}
\hline \multirow{2}{*}{} & \multicolumn{3}{|c|}{ Kolmogorov-Smirnov } & \multicolumn{3}{c|}{ Shapiro-Wilk } \\
\cline { 2 - 7 } & Statistic & $\boldsymbol{d f}$ & Sig. & Statistic & $\boldsymbol{d f}$ & Sig. \\
\hline CS & .199 & 100 & .180 & .944 & 100 & .222 \\
\hline PS & .155 & 100 & .200 & .967 & 100 & .341 \\
\hline
\end{tabular}

Information:

CA $=$ Collaborative skills

PSA $=$ Problem solving skills

Table 5. Independent sample $t$ test

\begin{tabular}{|l|l|c|c|c|c|c|c|c|c|c|}
\hline \multicolumn{2}{|l|}{} & F & Sig. & t & df & $\begin{array}{c}\text { Sig. } \\
\text { (2-tailed) }\end{array}$ & Mean Difference & $\begin{array}{c}\text { Std. Error } \\
\text { difference }\end{array}$ & lower & upper \\
\hline CS & EVA & \multirow{2}{*}{199} & \multirow{2}{*}{.76} & 11.33 & 100 & .00 & 23.65 & 1.83 & 15.94 & 19.87 \\
& EVNA & & & 12.95 & 95.42 & .00 & 23.65 & 1.71 & 15.92 & 19.71 \\
\hline \multirow{2}{*}{ PS } & EVA & \multirow{2}{*}{1.98} & \multirow{2}{*}{.13} & 14.99 & 100 & .00 & 19.81 & 1.33 & 14.16 & 19.96 \\
& EVNA & & & 14.71 & 90.56 & .00 & 19.81 & 1.31 & 14.41 & 19.33 \\
\hline
\end{tabular}

Information:

$\mathrm{CA}=$ Collaborative skills

PSA $=$ Problem solving skills

$\mathrm{EVA}=$ Equal Variances assumed

EVNA $=$ Equal variances not assumsed

In Table 3, the result of Lavene's homogeneity in collaborative skills was 0.435 with a significance result of 0.695 , so that the collaborative skills of students were a homogeneous group. Meanwhile, the homogeneity of Lavene on problem-solving skills was 0.404 with a significance result of 0.499 , so that the problem-solving skills of students was also a homogeneous group. In Table 4, the Kolmogorov-Smirnov calculation results and the Shapiro-Wilk collaborative skills test were 0.222 , which meant that the data was normally distributed. Then the results of the Kolmogorov-Smirnov count and the Shapiro-Wilk test of problem-solving skills was 0.341 , which meant that the data were normally distributed. Table 5 showed that the t-test results of the independent sample test of collaborative skills in the equal variance assumed showed a result of $0.000<0.05$, which indicated a significant difference before and after the implementation of CPMM. Meanwhile, the independent sample t-test result of problem-solving 
skills in equal variance assumed showed a result of $0.000<0.05$, which indicated a significant difference before and after the implementation or use of CPMM. From the homogeneity test, normality test, and t test results, it could be said that CPMM was effectively used to improve student collaborative skills and problem-solving.

\subsection{Discussion}

The CPMM development results in this study produce three main features, namely homepage, collaborative, and evaluation. The homepage feature is used to show student profiles and progress in courses. The mobile features that can record student achievement progress will cause students to have a positive perception of learning and learning awareness [21],[22]. In addition, the progress of the achievements recorded every time will form an initial self-evaluation and independently to always learn to improve and learn to prepare to be better prepared for the next lesson [23].

Collaborative features serve to become a place for students to discuss and interact in multi-way mobile ways to solve problems. Mobile features that present a collaborative element are seen as the main requirement for completing mobile in-active multimedia to construct digital knowledge [24]. The advantage of the collaborative component of learning is that knowledge is formed inductively between students as peers [25]. Besides, that collaboration does not mean eliminating the role of lecturers as educators but instead strengthening the position of lecturers as learning facilitators. In this case, educators must constantly update their knowledge and monitor the development of student competencies more effectively [26]. The involvement of multidirectional interactions between students and lecturers in CPMM also strengthens the learning atmosphere in the classroom (mobile version) so that trust and a sense of cooperation are always built in dealing with a problem [24], [25].

The evaluation feature serves as tasks from the lecturer to individual students to solve problems. Mobile features that have an element of evaluation as a form of a final assessment of student competencies are seen as a type of in-active mobile multimedia that can give students confidence that their performance is valued and gets feedback [25]. This is important to develop student knowledge in good condition because it is always assessed from time to time [23].

Using CPMM in learning also shows features of initial safety, collaborative, and continuous and gradual evaluation valid and effective can train student collaborative skills through problem-solving tasks. This study supports the results of previous studies that the presence of interactive multimedia mobile, which presents an element of collaborative discussion, will effectively improve student learning performance. In addition, face-to-face learning gaps can also be overcome that interactive multimedia mobile provides a more conditional and easy learning solution according to student needs [27]. In other words, CPMM as a type of interactive multimedia mobile can be a solution and an initial breakthrough for practicing collaborative skills and problem-solving as 21 st-century skills that are important and fundamental [15],[28]. Habitual and use of technology that focuses on collaborative skills and digital problem solving are also seen as a real effort to achieve 21 st-century skills as a whole to prepare graduates and generations who survive and are innovative in the era of revolution 4.0 [1]. 


\section{Conclusion}

CPMM development produced three main features, namely the homepage, collaborative, and evaluation. These features work continuously and gradually to train students' collaborative skills through problem-solving tasks. Collaborative features play an essential role in familiarizing collaborative and problem-solving skills during learning using CPMM. This critical role occurs when students discuss, interact in multi-directions, and make decisions about solving strategies for the problems given. Based on theoretical validity and empirical validity, the CPMM is also feasible and effective to improve student collaborative skills and problem-solving as fundamental 21 st-century skills and has the potential to enhance overall 21 st century skills to produce graduates who are ready to face the revolution era 4.0.

\section{$5 \quad$ References}

[1] N. Baharin, N. Kamarudin, and U. K. A. Manaf, "Integrating STEM education approach in enhancing higher order thinking skills," Int. J. Acad. Res. Bus. Soc. Sci., vol. 8, no. 7, pp. 810-821, 2018. https://doi.org/10.6007/ijarbss/v8-i7/4421

[2] J. Voogt and N. P. Roblin, "A comparative analysis of international frameworks for $21 \mathrm{st}$ century competences: Implications for national curriculum policies," J. Curric. Stud., vol. 44, no. 3, pp. 299-321, Jun. 2012. https://doi.org/10.1080/00220272. 2012.668938

[3] M. W. Meyer and D. Norman, "Changing Design Education for the 21st Century," She Ji J. Des. Econ. Innov., vol. 6, no. 1, pp. 13-49, 2020.

[4] PISA, PISA 2021 mathematics framework. New York: OECD Publishing, 2021.

[5] R. S. Malik, "Educational Challenges in 21St Century and Sustainable Development," J. Sustain. Dev. Educ. Res., vol. 2, no. 1, p. 9, 2018.

[6] E. Van Laar, A. J. A. M. Van Deursen, J. A. G. M. Van Dijk, and J. De Haan, "The relation between 21st-century skills and digital skills: A systematic literature review," Comput. Human Behav., vol. 72, pp. 577-588, 2017. https://doi.org/10. 1016/j.chb.2017.03.010

[7] M. Frydenberg and D. Andone, "Learning for 21st century skills," in International Conference on Information Society (i-Society 2011), 2011, pp. 314-318. https://doi.org/10.1109/isociety 18435.2011 .5978460

[8] Á. Suárez, M. Specht, F. Prinsen, M. Kalz, and S. Ternier, "A review of the types of mobile activities in mobile inquiry-based learning," Comput. Educ., vol. 118, pp. 38-55, 2018. https://doi.org/10.1016/j.compedu.2017.11.004

[9] M. T. Magiera and J. S. Zawojewski, "Characterizations of Social-Based and Self-Based Contexts Associated With Students' Awareness, Evaluation, and Regulation of Their Thinking During Small-Group Mathematical Modeling," J. Res. Math. Educ., vol. 42, no. 5, p. 486, 2011. https://doi.org/10.5951/jresematheduc.42.5.0486

[10] D. Frohberg, C. Göth, and G. Schwabe, "Mobile Learning projects - a critical analysis of the state of the art," J. Comput. Assist. Learn., vol. 25, no. 4, pp. 307-331, Jul. 2009. https://doi.org/10.1111/j.1365-2729.2009.00315.x

[11] M. F. Amir, F. N. Hasanah, and H. Musthofa, "Interactive Multimedia Based Mathematics Problem Solving to Develop Student s' Reasoning," Int. J. Eng. Technol., vol. 7, no. 2.14, pp. 272-276, 2018. 
[12] D. Parsons, H. Y. Ryu, and M. Cranshaw, "A design requirements framework for mobile learning environments," JCP, vol. 2, no. 4, pp. 1-8, 2007. https://doi.org/10.4304/jcp.2.4.1$\underline{8}$

[13] M. Sharples and J. Roschelle, "Guest editorial: Special issue on mobile and ubiquitous technologies for learning," IEEE Trans. Learn. Technol., vol. 3, no. 1, pp. 4-5, 2010. https://doi.org/10.1109/ttt.2010.7

[14] P. Dillenbourg and Z. Crivelli, "A Model of Collaborative Learning Scripts Instantiated with Mobile Technologies," Int. J. Mob. Blended Learn., vol. 1, no. 1, pp. 36-48, Jan. 2009. https://doi.org/10.4018/jmbl.2009010103

[15] M. B. U. Arifin, M. Sholeh, A. Hafiz, R. D. Agustin, and M. D. K. Wardana, "Developing Interactive Mobile Mathematics Inquiry to Enhance Students' Mathematics Problem-solving Skill," Int. J. Interact. Mob. Technol., vol. 15, no. 1, pp. 24-38, 2021. https://doi.org/10.3991/ijim.v15i01.20067

[16] A. C. Luther, Authoring interactive multimedia. England: Academic Press Professional, Inc., 1994.

[17] H. Taherdoost, "Sampling Methods in Research Methodology; How to Choose a Sampling Technique for Research," Int. J. Acad. Res. Manag., vol. 5, p. 02546796, 2016. https://doi.org/10.2139/ssrn.3205035

[18] Y. C. Yeh, "Integrating collaborative PBL with blended learning to explore preservice teachers' development of online learning communities," Teach. Teach. Educ., vol. 26, no. 8, pp. 1630-1640, 2010. https://doi.org/10.1016/j.tate.2010.06.014

[19] G. Polya, How to Solve it? Princeton, NJ: Princeton University Press, 1945.

[20] J. M. Bland and D. G. Altman, "Statistics notes: Cronbach's alpha," BMJ, vol. 314, no. 7080, pp. 572-572, Feb. 1997. https://doi.org/10.1136/bmj.314.7080.572

[21] G. D. Chen, C. K. Chang, and C. Y. Wang, "Ubiquitous learning website: Scaffold learners by mobile devices with information-aware techniques," Comput. Educ., vol. 50, no. 1, pp. 77-90, Jan. 2008. https://doi.org/10.1016/j.compedu.2006.03.004

[22] M. F. Amir, N. Fediyanto, H. E. Rudyanto, D. S. N. Afifah, and H. S. Tortop, "Elementary students' perceptions of 3Dmetric : A cross-sectional study," Heliyon, vol. 6, no. 6, pp. 1-8, 2020. https://doi.org/10.1016/j.heliyon.2020.e04052

[23] V. Klenowski, "Student Self-evaluation Processes in Student-centred Teaching and Learning Contexts of Australia and England," Assess. Educ. Princ. Policy Pract., vol. 2, no. 2, pp. 145-163, Aug. 1995. https://doi.org/10.1080/0969594950020203

[24] H. Z. Baloch, A. Abdul Rahman, and N. A Ihad, "Mobile Collaborative Informal Learning Design: Study of collaborative effectiveness using Activity Theory," Int. J. Interact. Mob. Technol., vol. 6, no. 3, p. 34, 2012. https://doi.org/10.3991/ijim. v6i3.2090

[25] R. Cruz Flores and G. López Morteo, "A Framework for Educational Collaborative Activities Based on Mobile Devices: A Support to the Instructional Design," Int. J. Interact. Mob. Technol., vol. 4, no. 3, p. 9, 2010. https://doi.org/10.3991/ijim. v4i3.1268

[26] M. F. Amir, N. Ariyanti, N. Anwar, E. Valentino, and D. S. N. Afifah, "Augmented Reality Mobile Learning System : Study to Improve PSTs' Understanding of Mathematical Development," Int. J. Interact. Mob. Technol., vol. 14, no. 9, pp. 239-247, 2020. https://doi.org/10.3991/ijim.v14i09.12909

[27] R. Zheng and B. Zhou, "Recency effect on problem solving in interactive multimedia learning," Educ. Technol. Soc., vol. 9, no. 2, pp. 107-118, 2006.

[28] Y. Song, "Improving primary students' collaborative problem solving competency in project-based science learning with productive failure instructional design in a seamless learning environment," Educ. Technol. Res. Dev., vol. 66, no. 4, pp. 979-1008, 2018. https://doi.org/10.1007/s11423-018-9600-3 


\section{Authors}

Endah Hendarwati is a lecturer at the University of Universitas Muhammadiyah Surabaya. He is also currently pursuing a doctoral program at Universitas Negeri Surabaya, Indonesia. Her main research interest areas are technological innovation and learning. Email: endah.17070996007@mhs.unesa.ac.id

Luthfiyah Nurlaela is a lecturer in the education technology study program at the Universitas Negeri Surabaya, Indonesia. Her main research interest area is learning strategies.

Bachtiar Syaiful Bachri a lecturer at the educational technology study program, Universitas Negeri Surabaya, Indonesia. His main research interest areas are curriculum and instruction.

Article submitted 2021-04-06. Resubmitted 2021-05-12. Final acceptance 2021-05-15. Final version published as submitted by the authors. 